University of Nebraska - Lincoln

DigitalCommons@University of Nebraska - Lincoln

West Central Research and Extension Center, North Platte

Agricultural Research Division of IANR

2011

\title{
CASE STUDY: The effects of maternal nutrition on steer progeny performance
}

A. F. Summers

University of Nebraska, West Central Research and Extension Center, adamfsummers@gmail.com

K. H. Ramsay

Rex Ranch

Richard N. Funston

University of Nebraska - Lincoln, rfunston2@unl.edu

Follow this and additional works at: https://digitalcommons.unl.edu/westcentresext

Part of the Agriculture Commons

Summers, A. F.; Ramsay, K. H.; and Funston, Richard N., "CASE STUDY: The effects of maternal nutrition on steer progeny performance" (2011). West Central Research and Extension Center, North Platte. 50. https://digitalcommons.unl.edu/westcentresext/50

This Article is brought to you for free and open access by the Agricultural Research Division of IANR at DigitalCommons@University of Nebraska - Lincoln. It has been accepted for inclusion in West Central Research and Extension Center, North Platte by an authorized administrator of DigitalCommons@University of Nebraska Lincoln. 

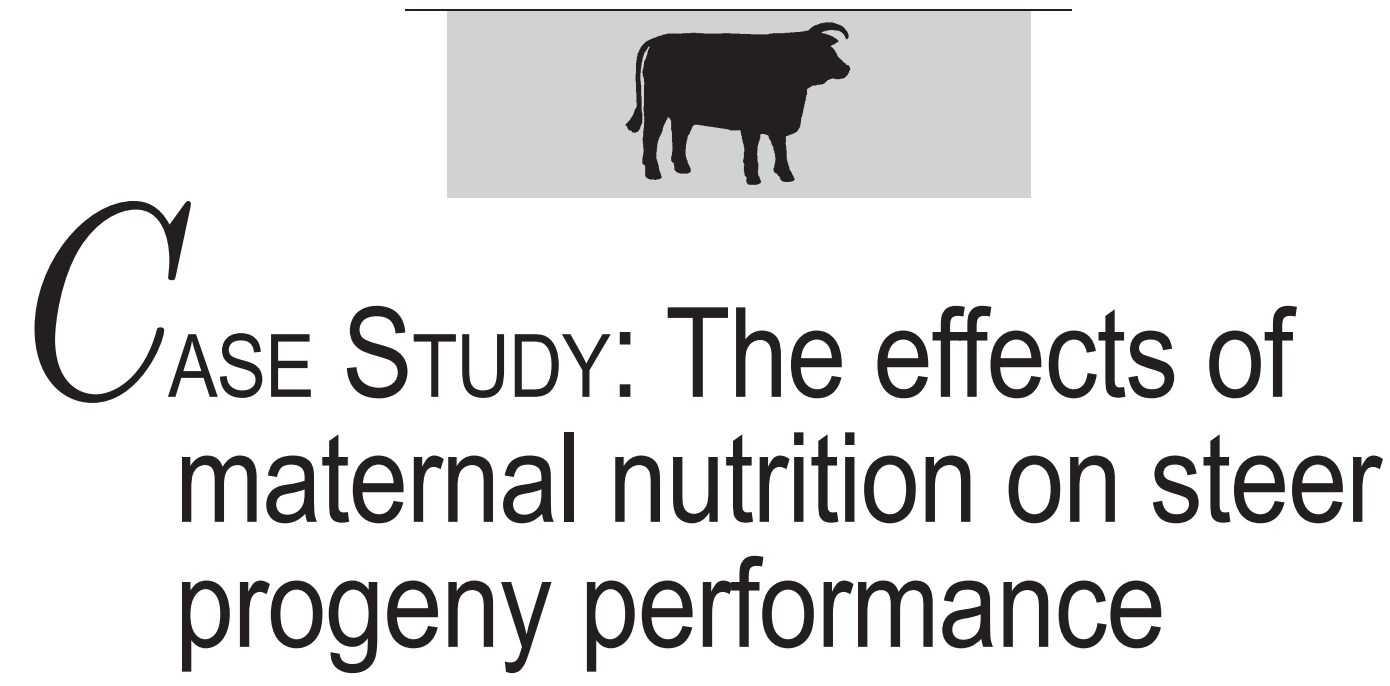

\author{
A. F. Summers, ${ }^{*}$ K. H. Ramsay, $†$ and R. N. Funston ${ }^{\star 1}$ \\ *University of Nebraska, West Central Research and Extension Center, North Platte 69101; and \\ †Rex Ranch, Ashby, NE 69333
}

\begin{abstract}
Two locations on a commercial ranch in the Nebraska Sandhills were used to determine the effects of maternal nutrition on male progeny. Crossbred, spring-calving, multiparous cows were managed in a year-round grazing system. Cows at one location (yr 1 = 754; yr 2 $=700)$ received the equivalent of 0.95 $\mathrm{kg} / \mathrm{d}(\mathrm{DM} ; 31.6 \% \mathrm{CP} ; \mathrm{HN})$ of supplement, and cows at the second location (yr $1=673 ;$ yr $2=766)$ received 0.37 $\mathrm{kg} / \mathrm{d}(D M ; L N)$ of the same supplement delivered 3 times weekly while grazing winter range from December through February. After weaning, a random group (yr $1=50 \mathrm{HN}, 50 \mathrm{LN}$; yr $2=50$ $H N, 50 \mathrm{LN}$ ) of male progeny entered the feedlot and were slaughtered 218 d later. There was a significant $(P \leq 0.03)$ year $x$ treatment interaction, with $y r-1 \mathrm{HN}$ steers having the greatest reimplant $B W$, final BW, DMI, G:F ratios, and $H C W$.

Year-2 HN steers had greater $(P=0.03)$ proportions grading USDA Choice or greater compared with yr-1 $H N$ and $L N$ steers. Marbling scores were greater for $H N$ steers compared with LN steers ( $P$ $=0.05)$ and steers from yr 2 compared with yr $1(P<0.01)$. Year-2 steers had greater $(P<0.01)$ proportions grading USDA Choice compared with yr-1 steers. Increased maternal nutrition resulted in
\end{abstract}

\footnotetext{
${ }^{1}$ Corresponding author: rfunston2@unl.edu
}

increased steer performance and carcass characteristics in yr 1 and greater marbling scores in HN steers compared with LN steers.

Key words: beef cattle, carcass quality, maternal nutrition

\section{INTRODUCTION}

Minimizing costs while maximizing profitability is a major goal in beef cattle production. Utilizing dormant forages throughout the winter reduces production costs by increasing grazing season length and decreasing the amount of harvested forage needed in beef cattle production systems (Adams et al., 1994); however, nutrient content of dormant forage is low and does not meet the energy demands of cows during the last trimester of gestation (NRC, 2000). Not meeting energy requirements of the dam not only influences dam productivity, but the performance of subsequent offspring as well (Houghton et al., 1990; Dunn and Moss, 1992; Beaty et al., 1994; Wu et al., 2004; Hess et al., 2005; Underwood et al., 2010). Providing protein supplementation through winter grazing has been a common practice to maintain cow BCS (Banta et al., 2006; Stalker et al., 2006; Martin et al., 2007; Larson et al., 2009). Providing pro- tein supplementation has increased progeny weaning BW (Stalker et al., 2006; Martin et al., 2007), improved postweaning calf health (Mulliniks et al., 2008; Larson et al., 2009), and increased $\mathrm{HCW}$ and the proportion of calves achieving USDA quality grades of Choice or greater (Larson et al., 2009). These results indicate maternal nutrition during gestation can influence postnatal growth and health, hypothesized as fetal programming (Barker et al., 1993). The objective of the current study was to evaluate the effects of 2 protein supplementation levels for dams grazing dormant Sandhills forage on subsequent steer progeny growth, feed efficiency, and carcass traits.

\section{MATERIALS AND METHODS}

\section{Cow and Calf Management}

The University of Nebraska-Lincoln Institutional Animal Care and Use Committee approved the procedures and facilities used in this experiment. A 2-yr study was conducted at 2 units of the Rex Ranch, Ashby, Nebraska. Pregnant, multiparous, composite beef cows of similar genetics (50\% Red Angus, $25 \%$ Simmental, and 25\% South Devon or other breeds) were managed in a year-round grazing system. Cows were pasture exposed to bulls of simi- 


\section{Table 1. Composition of backgrounding and finishing diets fed to steer progeny of $\mathrm{HN}$ and $\mathrm{LN}$ cows ${ }^{1}$}

\begin{tabular}{|c|c|c|}
\hline \multirow[b]{2}{*}{ Item } & \multicolumn{2}{|c|}{ DM, \% } \\
\hline & Backgrounding $^{2}$ & Finishing $^{3}$ \\
\hline Dry-rolled corn & 15 & 48 \\
\hline Wet corn gluten feed & 40 & 40 \\
\hline Grass hay & 35 & 7 \\
\hline Supplement ${ }^{4}$ & 10 & 5 \\
\hline
\end{tabular}

${ }^{1} \mathrm{HN}=$ dams supplemented with 1.06 and $0.83 \mathrm{~kg} / \mathrm{d}$ of $31.6 \% \mathrm{CP}$ cube (DM basis)

during late gestation and 5.63 and $4.86 \mathrm{~kg} / \mathrm{d}$ of meadow hay during calving for $\mathrm{yr}$

1 and 2, respectively; $\mathrm{LN}=$ dams supplemented with 0.35 and $0.38 \mathrm{~kg} / \mathrm{d}$ of protein

supplement during late gestation and 4.14 and $5.83 \mathrm{~kg} / \mathrm{d}$ of meadow hay during

calving for yr 1 and 2 , respectively.

${ }^{2}$ Contained $16 \% \mathrm{CP}, 1.1 \% \mathrm{Ca}, 0.58 \% \mathrm{P}$, and $1.2 \% \mathrm{~K}$ (DM basis).

${ }^{3}$ Contained $14 \% \mathrm{CP}, 0.67 \% \mathrm{Ca}, 0.56 \% \mathrm{P}$, and $0.9 \% \mathrm{~K}$ (DM basis).

${ }^{4}$ Provided dietary concentration of $28 \mathrm{~g} / \mathrm{t}$ of monensin and $10 \mathrm{~g} / \mathrm{t}$ of tylosin (DM basis, Elanco Animal Health, Indianapolis, IN).

lar breeding at each location for $70 \mathrm{~d}$ beginning mid-June through August. Forty-five days after the breeding season, pregnancy rates were determined via rectal palpation.

Cows grazed dormant forage pastures of similar quality (Patterson et al., 2003) from November to late February with a protein supplement (31.6\% CP cubes) delivered 3 times weekly. The supplement offered was similar to that reported by Larson et al. (2009) and contained $62.0 \%$ dried distillers grains plus solubles, $11.0 \%$ wheat middlings, $9.0 \%$ cottonseed meal, $5.0 \%$ dried corn gluten feed, $5.0 \%$ molasses, $2.0 \%$ urea, and $6.0 \%$ vitamin and trace mineral premix on a DM basis. The supplement was formulated to meet vitamin and trace mineral requirements of the 3 -yr-old cows and supply $80 \mathrm{mg}$ of monensin per day per animal (Rumensin, Elanco Animal Health, Indianapolis, IN). The supplement provided was approximately $47.6 \%$ RUP and $89.4 \%$ TDN on a DM basis (Larson et al., 2009).

Supplement and meadow hay were offered to cows at both locations at the discretion of the manager, with cows at one location (yr $1=754$; yr $2=700$ ) receiving higher levels of supplement $(\mathbf{H N} ; 1.06 \mathrm{~kg} / \mathrm{d}$ yr 1 ; $0.83 \mathrm{~kg} / \mathrm{d}$ yr $2, \mathrm{DM}$ basis) and cows at the second location (yr $1=673$; yr $2=766$ ) being fed lower levels of supplement (LN; $0.35 \mathrm{~kg} / \mathrm{d}$ yr $1 ; 0.38$ $\mathrm{kg} / \mathrm{d}$ yr 2, DM basis). During calving (March and April), cows received meadow hay in the form of large round bales, with HN cows receiving $5.63 \mathrm{~kg} / \mathrm{d}(\mathrm{DM})$ in yr 1 and $4.86 \mathrm{~kg} / \mathrm{d}$ (DM) in yr 2 and LN cows receiving 4.14 and $5.83 \mathrm{~kg} / \mathrm{d}(\mathrm{DM})$ in yr 1 and yr 2, respectively. Differing levels of supplementation and hay fed resulted from managers at each of the 2 units feeding the cows at their discretion. After weaning (early to mid-September), calves grazed meadow pasture while receiving $1.21 \mathrm{~kg} / \mathrm{d}(\mathrm{DM})$ of the CP supplement until shipping in midNovember.

\section{Steer Calf Management}

Each year a random sample of steers from each treatment group $(50 \mathrm{HN}$, $50 \mathrm{LN}$ ) was shipped approximately $212 \mathrm{~km}$ to the University of Nebraska West Central Research and Extension Center, North Platte, Nebraska. All steers were fed together in one pen and limit fed a starter diet (Table 1) for $5 \mathrm{~d}$ after arrival; steers were then weighed on 2 consecutive days to calculate initial BW. On the second day an implant was administered providing $20 \mathrm{mg}$ of estradiol benzoate and
$200 \mathrm{mg}$ of progesterone (Synovex S, Fort Dodge Animal Health, Overland Park, KS). Steers were transitioned to a finishing diet (Table 1) over $21 \mathrm{~d}$. Approximately $100 \mathrm{~d}$ before slaughter, steers were implanted with $24 \mathrm{mg}$ of estradiol and $120 \mathrm{mg}$ of trenbolone acetate (Revalor S, Intervet, Millsboro, DE). Steers were slaughtered at a commercial abattoir $218 \mathrm{~d}$ after entering the feedlot. Final BW was calculated from $\mathrm{HCW}$ divided by a common dressing percentage (63\%), and carcass data were collected after a 24-h chill.

Steer DMI was calculated using the DMI prediction equation established by Tedeschi et al. (2006), where DMI $=4.18+(1.98 \times \mathrm{ADG})+(0.0013$ $\left.\times \mathrm{MBW}^{0.75}\right)+(0.019 \times \mathrm{EBF})$, where $\mathrm{MBW}^{0.75}$ represents the mean metabolic BW and EBF represents empty body fat percentage. Empty body fat percentage was calculated using the equation developed by Guiroy et al. (2001), where $\mathrm{EBF}=17.76107+$ $(4.68142 \times \mathrm{FT})+(0.01945 \times \mathrm{HCW})$ $+(0.81855 \times \mathrm{QG})-(0.06754 \times$ LMA), where FT represents 12th-rib fat thickness and LMA represents LM area.

\section{Economic Evaluation}

To determine the effect of the 2 supplementation levels on profitability, a partial budget analysis was conducted. Supplementation costs were valued at actual purchase price plus a delivery charge $(\$ 0.07 / \mathrm{kg})$. Meadow hay values were taken from Nebraska state average monthly price based on the USDA Agricultural Marketing Service (USDA-AMS, 2007a, 2008a). Calf sale prices were Nebraska weighted average feeder cattle price reported for the given year at the time of entry into the feedlot as reported by the USDA Agricultural Marketing Service (USDA-AMS, 2007b, 2008b). Feedlot ration was valued at $\$ 0.14 / \mathrm{kg}$. Veterinary charges, trucking, yardage, and implants were charged as nonfeed costs at $\$ 0.50 / \mathrm{d}$. The value of steers at slaughter was based on Nebraska dressed steer price for the day of slaughter (USDA-AMS, 2008c, 
2009a), with grid premiums and discounts applied as reported by the USDA Agricultural Marketing Service (USDA-AMS, 2008d, 2009b).

\section{Statistical Analysis}

Supplementation levels were applied to the dams on a location level $(\mathrm{n}=1)$ repeated over a 2 -yr period; therefore, location was considered the experimental unit for steer performance and carcass data. Data were analyzed using PROC MIXED (SAS Inst. Inc., Cary, NC), with $P \leq 0.05$ considered significant. The statistical model included dam treatment, year, and dam treatment $\times$ year. Proportions of steers grading USDA Choice and USDA QG of modest or higher were analyzed using $\chi^{2}$ procedures in PROC FREQ of SAS.

\section{RESULTS AND DISCUSSION}

\section{Performance and Carcass Quality}

Steer feedlot performance data are presented in Table 2. Initial BW did not differ $(P=0.17)$ between $\mathrm{HN}$ and LN steers; however, steers in yr 1 were $23 \mathrm{~kg}$ heavier $(P<0.01)$ than steers from the same treatments in yr
2. These data for initial BW disagree with previous studies in which calves from supplemented or increased supplemented dams had greater weaning weights and feedlot initial BW (Beaty et al., 1994; Spitzer et al., 1995; Stalker et al., 2006; Larson et al., 2009). Calves entering the feedlot from those studies were placed in the feedlot $14 \mathrm{~d}$ postweaning, whereas calves in this study were not shipped to the feedlot until approximately 8 wk after weaning and were allowed to graze subirrigated meadows and received $1.21 \mathrm{~kg} / \mathrm{d}$ of $31.6 \% \mathrm{CP}$ supplement. In the studies conducted by Stalker et al. (2006) and Larson et al. (2009), pregnant cows were offered the equivalent of $0.45 \mathrm{~kg} / \mathrm{d}$ supplement or no supplement. In the present study, cows were provided supplement at both locations, with $\mathrm{HN}$ cows receiving approximately 2.5 times more supplement than LN cows, and LN cows receiving supplement levels similar to Stalker et al. (2006) and Larson et al. (2009). Reimplant BW $(P=0.03)$ and final BW $(P=0.01)$ were greatest for yr-1 HN steers. Average daily gain, DMI, and efficiency calculated as G:F were greatest $(P<$ $0.01)$ for yr- $1 \mathrm{HN}$ steers.

Steer carcass data are summarized in Table 3. Hot carcass weight was greater $(P=0.01)$ for yr-1 HN steers compared with steers from all other groups. The proportion of steers grading USDA Choice was 32 and $33 \%$ greater $(P<0.01)$ for $\mathrm{HN}$ and $\mathrm{LN}$ steers from yr 2 compared with yr 1 . Furthermore, yr-2 HN steers had a greater $(P=0.03)$ proportion grading USDA modest or greater compared with yr-1 HN and LN steers.

Steers from HN cows had greater marbling scores compared with steers from LN cows (434 vs. $415, \pm 7, P \leq$ $0.05)$, and yr-2 steers had greater $(P$ $<0.01)$ marbling scores compared with yr-1 steers. In a review on fetal skeletal muscle development, Du et al. (2010) reported the importance of maternal nutrition on muscle development and the ability to increase intramuscular fat deposits through recruitment of mesenchymal stem cells to adipogenesis rather than myogenesis, which later lead to marbling. It is hypothesized greater marbling scores reported in HN steers compared with LN steers results from fetal programming.

There were no differences $(P \geq$ $0.26)$ in 12th-rib fat, LM area, or YG when comparing steers from $\mathrm{HN}$ cows to those from LN cows; however, differences were significant $(P<0.08)$ between yr 1 and yr 2 . No differences

Table 2. Effects of late-gestation maternal protein supplementation level on progeny steer feedlot performance

\begin{tabular}{|c|c|c|c|c|c|c|c|c|}
\hline \multirow[b]{3}{*}{ Item } & \multicolumn{4}{|c|}{ Treatment $^{1}$} & \multirow[b]{3}{*}{ SEM } & \multirow{2}{*}{\multicolumn{3}{|c|}{ Treatment $\boldsymbol{P}$-value $^{2}$}} \\
\hline & \multicolumn{2}{|c|}{$\mathrm{HN}$} & \multicolumn{2}{|c|}{ LN } & & & & \\
\hline & Yr 1 & Yr 2 & Yr 1 & Yr 2 & & Trt & Yr & Trt $\times$ Yr \\
\hline Initial BW, kg & 239 & 216 & 236 & 213 & 2 & 0.17 & $<0.01$ & 0.82 \\
\hline Reimplant BW, kg & $459^{a}$ & $410^{c}$ & $443^{b}$ & $412^{c}$ & 4 & 0.09 & $<0.01$ & 0.03 \\
\hline Final BW, kg & $631^{a}$ & $570^{c}$ & $605^{b}$ & $574^{c}$ & 6 & 0.07 & $<0.01$ & 0.01 \\
\hline$A D G, \mathrm{~kg} / \mathrm{d}$ & $1.80^{\mathrm{a}}$ & $1.62^{\mathrm{b}}$ & $1.69^{b}$ & $1.66^{b}$ & 0.02 & 0.11 & $<0.01$ & $<0.01$ \\
\hline $\mathrm{DMI},{ }^{3} \mathrm{~kg} / \mathrm{d}$ & $8.41^{a}$ & $8.05^{b}$ & $8.19^{b}$ & $8.13^{b}$ & 0.09 & 0.12 & $<0.01$ & $<0.01$ \\
\hline $\mathrm{G}: F, \mathrm{~g} / \mathrm{kg}$ & $213.67^{a}$ & $200.63^{b}$ & $206.12^{b}$ & $203.57^{b}$ & 1.27 & 0.15 & $<0.01$ & $<0.01$ \\
\hline
\end{tabular}

${ }^{\mathrm{a}-\mathrm{c} M e a n s}$ within a row with different superscripts differ $(P<0.05)$.

${ }^{1} \mathrm{HN}=$ dams supplemented with 1.06 and $0.83 \mathrm{~kg} / \mathrm{d}$ of $31.6 \% \mathrm{CP}$ cube (DM basis) during late gestation and 5.63 and $4.86 \mathrm{~kg} / \mathrm{d}$ of meadow hay during calving for yr 1 and 2, respectively; $L N=$ dams supplemented with 0.35 and $0.38 \mathrm{~kg} / \mathrm{d}$ of protein supplement during late gestation and 4.14 and $5.83 \mathrm{~kg} / \mathrm{d}$ of meadow hay during calving for $\mathrm{yr} 1$ and 2, respectively.

${ }^{2} \mathrm{Trt}=$ dam treatment; $\mathrm{Yr}=$ year; $\mathrm{Trt} \times \mathrm{Yr}=$ dam treatment by year interactions.

${ }^{3} \mathrm{DMI}$ calculated using the prediction formula presented by Tedeschi et al. $(2006)$, where $\mathrm{DMI}=4.18+(1.98 \times \mathrm{ADG})+(0.0013 \times$ $\left.\mathrm{MBW}^{0.75}\right)+(0.019 \times \mathrm{EBF})$, where $\mathrm{MBW}^{0.75}$ represents the mean metabolic BW and EBF represents empty body fat percentage. 
Table 3. Effects of late-gestation maternal protein supplementation level on progeny steer carcass data

\begin{tabular}{|c|c|c|c|c|c|c|c|c|}
\hline \multirow[b]{3}{*}{ Item } & \multicolumn{4}{|c|}{ Treatment $^{1}$} & \multirow[b]{3}{*}{ SEM } & \multirow{2}{*}{\multicolumn{3}{|c|}{ Treatment $\boldsymbol{P}$-value ${ }^{2}$}} \\
\hline & \multicolumn{2}{|c|}{ HN } & \multicolumn{2}{|c|}{ LN } & & & & \\
\hline & Yr 1 & Yr 2 & Yr 1 & Yr 2 & & Trt & $\mathrm{Yr}$ & Trt $\times$ Yr \\
\hline $\mathrm{HCW}, \mathrm{kg}$ & $397^{a}$ & $359^{c}$ & $381^{\mathrm{b}}$ & $362^{c}$ & 4 & 0.07 & $<0.01$ & 0.01 \\
\hline Marbling score ${ }^{3}$ & 410 & 458 & 388 & 441 & 10 & 0.05 & $<0.01$ & 0.79 \\
\hline 12th-rib fat, $\mathrm{cm}$ & 1.22 & 1.17 & 1.26 & 1.13 & 0.05 & 0.93 & 0.08 & 0.44 \\
\hline Empty body fat, \% & 28.62 & 28.92 & 28.48 & 28.78 & 0.33 & 0.67 & 0.36 & 0.99 \\
\hline $\mathrm{LM}$ area, $\mathrm{cm}^{2}$ & 94.38 & 81.39 & 93.03 & 79.96 & 1.25 & 0.26 & $<0.01$ & 0.96 \\
\hline YG & 2.74 & 3.02 & 2.71 & 3.07 & 0.10 & 0.95 & $<0.01$ & 0.64 \\
\hline QG, \% Sm 4 or greater & $46^{b}$ & $78^{a}$ & $48^{b}$ & $81^{a}$ & & 0.78 & $<0.01$ & $<0.01$ \\
\hline QG, $\% \mathrm{Md}^{5}$ of greater & $12^{\mathrm{bc}}$ & $29^{a}$ & $4^{c}$ & $19^{a b}$ & & 0.07 & $<0.01$ & 0.03 \\
\hline
\end{tabular}

${ }^{\mathrm{a}-\mathrm{c} M e a n s}$ within a row with different superscripts differ $(P<0.05)$.

${ }^{1} \mathrm{HN}=$ dams supplemented with 1.06 and $0.83 \mathrm{~kg} / \mathrm{d}$ of $31.6 \% \mathrm{CP}$ cube (DM basis) during late gestation and 5.63 and $4.86 \mathrm{~kg} / \mathrm{d}$ of meadow hay during calving for yr 1 and 2, respectively; LN = dams supplemented with 0.35 and $0.38 \mathrm{~kg} / \mathrm{d}$ of protein supplement during late gestation and 4.14 and $5.83 \mathrm{~kg} / \mathrm{d}$ of meadow hay during calving for $\mathrm{yr} 1$ and 2 , respectively.

${ }^{2} \mathrm{Trt}=$ dam treatment; $\mathrm{Yr}=$ year; $\mathrm{Trt} \times \mathrm{Yr}=$ dam treatment by year interactions.

${ }^{3}$ Where $400=$ small ${ }^{0}$.

${ }^{4} \mathrm{Sm}=$ small quality grade, USDA low Choice.

${ }^{5} \mathrm{Md}=$ modest quality grade, USDA average Choice.

( $P \geq 0.23)$ occurred between groups for empty body fat percentage.

Treatments in yr 1 differed slightly from yr 2 in amount of supplement provided; however, in both years, HN cows received greater levels of lategestation supplementation. Hay offered at calving did differ between yr 1 and yr 2, with HN cows from yr 1 receiving $1.49 \mathrm{~kg} / \mathrm{d}$ more hay than $\mathrm{LN}$ cows and in yr $2 \mathrm{LN}$ cows receiving $0.97 \mathrm{~kg} / \mathrm{d}$ more hay than HN cows. Differing levels of supplementation and hay fed resulted from managers at each of the 2 units feeding cows at their discretion. Nutrient availability both pre- and postpartum can influence milk production (Wiltbank et al., 1962; Totusek et al., 1973; Lalman et al., 2000), which may explain why there was no difference between treatments in yr 2. Johnson et al. (2003) reported an increase in milk production during early lactation of $1 \mathrm{~kg}$ of milk per $0.33 \mathrm{~kg}$ of forage DMI in Brangus cows. Although slightly different body maintenance requirements between Brangus and Angus cows are used by the NRC (2000) to calculate cow requirements, similar values are used for peak milk yield. Using values reported by Johnson et al. (2003), LN cows would be predicted to produce approximately $3 \mathrm{~kg}$ more milk compared with $\mathrm{HN}$ cows during early lactation of yr 2; however, milk production was not measured. The role of neonatal environment and its ability to influence postnatal programming have been reported (Francis et al., 1999; Drake and Walker, 2004). Increased nutrient availability at calving for LN cows, increasing early milk production, compared with HN cows could have influenced calf postnatal development, resulting in no significant differences between treatments in yr 2.

\section{Economic Evaluation}

Data for the economic evaluation are summarized in Table 4. Data represent actual values for the years of the study (2007 to 2009). In yr 1, if calves were sold in November, $\mathrm{HN}$ calves were valued at $\$ 9.19 /$ calf greater than calves from LN cows; however, net returns for $\mathrm{HN}$ calves were $\$ 8.84 /$ calf less than those for LN calves because of increased amounts of supplement and hay offered to HN cows. Year-2 calves also had greater sale values for $\mathrm{HN}$ calves. Unlike yr 1, $\mathrm{HN}$ calf value was $\$ 9.05$ /calf greater than that of LN calves because of increased hay amounts offered to LN cows during yr 2. Carcass value was greater for yr-1 steers compared with yr-2 steers from both treatments. In yr 1 , net profit difference through the feedlot phase was $\$ 40.63 /$ steer greater for steers born to HN cows compared with those born to LN cows; however, in yr 2 net profit difference was $\$ 16.88 /$ steer greater for LN steers compared with HN steers. Differences between returns are related to $\mathrm{HCW}$. In yr $1 \mathrm{HCW}$ was significantly greater $(P<0.01)$ for $\mathrm{HN}$ steers compared with LN calves, whereas in yr 2 difference in returns was due to a numerical, statistically nonsignificant, difference in HCW $(P=0.95)$. Fed cattle base prices were $\$ 0.09 / \mathrm{kg}$ higher in yr 1 compared with yr 2 , which along with the heavier HCW from yr 1 added to the differences in carcass values between the $2 \mathrm{yr}$. 


\section{Table 4. Partial budget analysis of maternal protein supplementation during late gestation to weaning and weaning to slaughter}

\begin{tabular}{|c|c|c|c|c|}
\hline \multirow[b]{3}{*}{ Item } & \multicolumn{4}{|c|}{ Treatment $^{1}$} \\
\hline & \multicolumn{2}{|c|}{ HN } & \multicolumn{2}{|c|}{ LN } \\
\hline & Yr 1 & Yr 2 & Yr 1 & Yr 2 \\
\hline \multicolumn{5}{|l|}{ Cow-calf phase } \\
\hline \multicolumn{5}{|l|}{ Costs, $\$$ /cow } \\
\hline Protein supplement & 6.60 & 5.17 & 2.18 & 2.37 \\
\hline Meadow hay & 51.15 & 45.52 & 37.54 & 54.53 \\
\hline \multicolumn{5}{|l|}{ Returns, \$/calf } \\
\hline Calf sale price ${ }^{2}$ & 626.28 & 469.95 & 617.09 & 467.11 \\
\hline Net profit difference & 568.53 & 419.26 & 577.37 & 410.21 \\
\hline \multicolumn{5}{|l|}{ Feedlot phase } \\
\hline \multicolumn{5}{|l|}{ Costs, $\$ /$ steer } \\
\hline Purchase cost ${ }^{3}$ & 661.70 & 509.41 & 654.09 & 500.38 \\
\hline Feedlot feed $\operatorname{cost}^{4}$ & 365.67 & 354.69 & 358.96 & 357.13 \\
\hline \multicolumn{5}{|l|}{ Returns, \$/steer } \\
\hline Carcass value & $1,302.63$ & $1,030.54$ & $1,247.68$ & $1,040.83$ \\
\hline Net profit difference & 275.26 & 166.44 & 234.63 & 183.32 \\
\hline
\end{tabular}

${ }^{1} \mathrm{HN}=$ dams supplemented with 1.06 and $0.83 \mathrm{~kg} / \mathrm{d}$ of $31.6 \% \mathrm{CP}$ cube (DM basis) during late gestation and 5.63 and $4.86 \mathrm{~kg} / \mathrm{d}$ of meadow hay during calving for $\mathrm{yr}$ 1 and 2, respectively; $L N=$ dams supplemented with 0.35 and $0.38 \mathrm{~kg} / \mathrm{d}$ of protein supplement during late gestation and 4.14 and $5.83 \mathrm{~kg} / \mathrm{d}$ of meadow hay during calving for yr 1 and 2, respectively.

${ }^{2}$ Value of steer calves after grazing meadow hay and receiving $1.21 \mathrm{~kg} / \mathrm{d}$ of $31.6 \% \mathrm{CP}$ cube (DM basis) for approximately 8 wk.

${ }^{3}$ Value of steer calves.

${ }^{4}$ Value based on $\$ 0.14 / \mathrm{kg}$ feed cost for $218 \mathrm{~d}$ and including yardage at $\$ 0.50 / \mathrm{d}$.

\section{IMPLICATIONS}

Providing increased late-gestation supplementation to the dam did not affect steer initial BW at feedlot entry; however, steers from $\mathrm{HN}$ cows in yr 1 had greater final BW and HCW than did steers from LN cows. Average marbling scores were greater for HN calves compared with LN calves, suggesting a fetal programming effect with increased dam supplementation altering fetal development. Based on these preliminary findings, additional research in a more controlled research environment is warranted to further elucidate effects of maternal nutrition on subsequent steer progeny.

\section{LITERATURE CITED}

Adams, D. C., R. T. Clark, S. A. Coady, J. B. Lamb, and M. K. Nielsen. 1994. Extended grazing systems for improving economic returns from Nebraska Sandhills cow/calf operations. J. Range Manage. 47:258.

Banta, J. P., D. L. Lalman, F. N. Owens, C. R. Krehbiel, and R. P. Wettemann. 2006. Effects of interval-feeding whole sunflower seeds during mid to late gestation on performance of beef cows and their progeny. J. Anim. Sci. 84:2410.

Barker, D. J. P., C. N. Martyn, C. Osmond, C. N. Hales, and C. H. D. Fall. 1993. Growth in utero and serum cholesterol concentrations in adult life. BMJ 307:1524.

Beaty, J. L., R. C. Cochran, B. A. Lintzenich, E. S. Vanzant, J. L. Morrill, R. T. Brandt, and D. E. Johnson. 1994. Effect of frequency of supplementation and protein concentration in supplements on performance and digestion characteristics of beef cattle consuming lowquality forages. J. Anim. Sci. 72:2475.

Drake, A. J., and B. R. Walker. 2004. The intergenerational effects of fetal programming:

Non-genomic mechanisms for the inheritance of low birth weight and cardiovascular risk. J. Endocrinol. 180:1.

Du, M, J. Tong, J. Zhao, K. R. Underwood, M. Zhu, S. P. Ford, and P. W. Nathanielsz. 2010. Fetal programming of skeletal muscle development in ruminant animals. J. Anim. Sci. 88(E. Suppl.):E51-E60.

Dunn, T. G., and E. G. Moss. 1992. Effects of nutrient deficiencies and excesses on reproductive efficiency of livestock. J. Anim. Sci. 70:1580.

Francis, D., J. Diorio, D. Liu, and M. J. Meaney. 1999. Nongenomic transmission across generations of maternal behavior and stress responses in the rat. Science 286:1155.

Guiroy, P. J., D. G. Fox, L. O. Tedeschi, M. J. Baker, and M. D. Cravey. 2001. Predicting individual feed requirements of cattle fed in groups. J. Anim. Sci. 79:1983.

Hess, B. W., S. L. Lake, E. J. Scholljegerdes, T. R. Weston, V. Nayigihugu, J. D. C. Molle, and G. E. Moss. 2005. Nutritional controls of beef cow reproduction. J. Anim. Sci. 83(E. Suppl.):E90-E106.

Houghton, P. L., R. P. Lemenager, L. A. Horstman, K. S. Hendrix, and G. E. Moss. 1990. Effects of body composition, pre- and postpartum energy level and early weaning on reproductive performance of beef cows and preweaning calf gains. J. Anim. Sci. 68:1438.

Johnson, C. R., D. L. Lalman, M. A. Brown, L. A. Appeddu, D. S. Buchanan, and R. P. Wettemann. 2003. Influence of milk production potential on forage dry matter intake by multiparous and primiparous Brangus females. J. Anim. Sci. 81:1837.

Lalman, D. L., J. E. Williams, B. W. Hess, M. G. Thomas, and D. H. Keisler. 2000. Effect of dietary energy on milk production and metabolic hormones in thin, primiparous beef heifers. J. Anim. Sci. 78:530.

Larson, D. M., J. L. Martin, D. C. Adams, and R. N. Funston. 2009. Winter grazing system and supplementation during late gestation influence performance of beef cows and steer progeny. J. Anim. Sci. 87:1147.

Martin, J. L., K. A. Vonnahme, D. C. Adams, G. P. Lardy, and R. N. Funston. 2007. Effects of dam nutrition on growth and reproductive performance of heifer calves. J. Anim. Sci. 85:841.

Mulliniks, J. T., S. H. Cox, S. L. Ivey, C. P. Mathis, J. E. Sawyer, and M. K. Petersen. 2008. Cow nutrition impacts feedlot pull rate. Proc. West. Sec. Am. Soc. Anim. Sci. 59:91.

NRC. 2000. Nutrient Requirements of Beef Cattle. 7th ed. Natl. Acad. Press, Washington, DC.

Patterson, H. H., D. C. Adams, T. J. Klopfenstein, R. T. Clark, and B. Teichert. 2003. Supplementation to meet metabolizable protein requirements of primiparous beef heifers: II. Pregnancy and economics. J. Anim. Sci. 81:563

Spitzer, J. C., D. G. Morrison, R. P. Wettemann, and L. C. Faulkner. 1995. Reproductive responses and calf birth and weaning weights as affected by body condition at parturition and postpartum weight gain 
in primiparous beef cows. J. Anim. Sci. 73:1251.

Stalker, L. A., D. C. Adams, T. J. Klopfenstein, D. M. Feuz, and R. N. Funston. 2006. Effects of pre- and postpartum nutrition on reproduction in spring calving cows and calf feedlot performance. J. Anim. Sci. 84:2582.

Tedeschi, L. O., D. G. Fox, M. J. Baker, and D. P. Kirschten. 2006. Identifying differences in feed efficiency among group-fed cattle. J. Anim. Sci. 84:767.

Totusek, R., D. W. Arnett, G. L. Holland, and J. V. Whiteman. 1973. Relation of estimation method, sampling interval and milk composition to milk yield of beef cows and calf gain. J. Anim. Sci. 37:153.

Underwood, K. R., J. F. Tong, P. L. Price, A. J. Roberts, E. E. Grings, B. W. Hess, W. J. Means, and M. Du. 2010. Nutrition during mid to late gestation affects growth, adipose tissue deposition and tenderness in cross-bred beef steers. Meat Sci. 86:588.
USDA-AMS. 2007a. Nebraska-Iowa weekly hay reports. Accessed March 1, 2010. http:// search.ams.usda.gov/mndms/2007/03/wh_ gr31020070315.txt.

USDA-AMS. 2007b. Nebraska weekly feeder cattle auction summary. Accessed March 1, 2010. http://search.ams.usda.gov/mndms/2007/11/WH_LS79520071119.txt.

USDA-AMS. 2008a. Nebraska-Iowa weekly hay reports. Accessed March 1, 2010. http:// search.ams.usda.gov/mndms/2008/03/WH_ GR31020080320.txt.

USDA-AMS. 2008b. Nebraska weekly feeder cattle auction summary. Accessed March 1, 2010. http://search.ams.usda.gov/mndms/2008/11/WH_LS79520081124.txt.

USDA-AMS. 2008c. 5 area weekly weighted average direct slaughter cattle. Accessed March 1, 2010. http://www.ams.usda.gov/ mnreports/lm_ct150.txt.

USDA-AMS. 2008d. National weekly direct slaughter cattle-premiums and discounts. Ac- cessed March 1, 2010. http://www.ams.usda. gov/mnreports/lm_ct155.txt.

USDA-AMS. 2009a. 5 area weekly weighted average direct slaughter cattle. Accessed March 1, 2010. http://www.ams.usda.gov/ mnreports/lm_ct150.txt.

USDA-AMS. 2009b. National weekly direct slaughter cattle-premiums and discounts. Accessed March 1, 2010. http://www.ams.usda. gov/mnreports/lm_ct155.txt.

Wiltbank, J. N., W. W. Rowden, J. E. Ingalls, K. E. Gregory, and R. M. Koch. 1962. Effects of energy level on reproductive phenomena of mature Hereford cows. J. Anim. Sci. 21:219.

Wu, G., F. W. Bazer, T. A. Cudd, C. J. Meininger, and T. E. Spencer. 2004. Maternal nutrition and fetal development. J. Nutr. 134:2169. 